\title{
World Literature in the World?
}

\section{Kahf's The Girl in the Tangerine Scarf and the Transnational Reading Public}

\author{
Maya Aghasi | ORCID: 0000-0002-4007-7200 \\ American University of Sharjah, Sharjah, UAE \\ maghasi@aus.edu
}

\begin{abstract}
Criticized for being too Euro- and Americentric, world literature scholarship tends to center on the American implications of this shortcoming, with little discussion of world literature beyond these centers. This paper thus addresses the function of world literature beyond these centers, particularly in the lingua franca of global business: English. Drawing from my experience in the United Arab Emirates, I argue that because students in the region come from places with fraught colonial histories, migrant, Anglophone literature is critical in the world literature classroom because it allows them to see their own experiences articulated in the global literary vernacular. Using Mohja Kahf's The Girl in the Tangerine Scarf as an example, I show how its transnational scope addresses both the hegemonic, Euro-American gaze, but also the students'. Thus, Anglophone literature is not necessarily the extension of an imperialist project or a flattening of differences; rather, it becomes an articulation of them.
\end{abstract}

\section{Keywords}

world literature - college teaching - Global English Department - globalization Middle East - Mohja Kahf

Ever since world literature courses have been taught in American institutions of higher education, there has always been the anxiety and critical selfawareness that world literature is too Euro- and Americentric. Even in 1959, before postcolonial criticism and multiculturalism burgeoned in academia, the "world" part of world literature was accused of being a misnomer because world literature courses taught primarily European texts (Smith 592). The Euro- 
Americentrism of the field and the self-conscious anxiety that came with it continue to define the field today. Postcolonial, minority, and international scholars are wary that courses in world literature continue to silence nonEuropean and non-canonical voices, finding that the field consists primarily of "First World academics reading and analyzing the works of Third World authors" (Suter 2). They fear that such an approach risks the "misreading of voices representing marginalized cultures" (Smith 596), "projecting Western values and interpretive codes onto non-Western texts in order to reach a Romanticist 'understanding' of those foreign cultures" (Smith 598). ${ }^{1}$ Indeed, Aamir Mufti has argued that this approach to world literature, the "bridging" of First and Third worlds, is the same Orientalist logic of imperialism (20), arguing that the rise of world literature came hand-in-hand with colonialism (19).

These criticisms are well-placed, but the problem with them lines up with the problem they critique. Reading practices labeled "world literature" as well as their criticisms tend to assume an American student body and a EuroAmerican academic community, as though world literature is not taught beyond these academic centers. ${ }^{2}$ Few have discussed their implications beyond them. Those who have assert that the English language itself is another central problematic in the field. Writing from Japan, Myles Chilton shows that,

because of its American pedagogical roots, world literature is often seen as merely the globalization of Anglophone literary studies - all the more so because, following teaching practice, world literature scholarship and commentary has emerged mostly from American universities and is conducted worldwide mostly in English.

94

1 I use Eurocentric and Americentric cognizant of how problematic each term is as well as of the power relations contained in each. "Europe" has problematically limited signification, referring mainly to western Europe and rendering invisible multiple languages and cultures predominantly from the Eastern part of the continent. As Theo D'haen has shown, certain European traditions, his example is Dutch literature, are in fact "minor" and tend to fall out of consideration unless "they serve 'major' interests" (8). Similarly, in spite of American political power and student interest, Damrosch has shown that, ironically, English departments in the US have sidelined American literature in favor of British and other European literatures ("How American?").

2 Though some may argue against the center-periphery paradigm, I agree with Chilton who compellingly argues that this logic still holds in English Studies Beyond The 'Center': Teaching Literature and the Future of Global English. 
James Hodapp, writing about his experience at the American University of Beirut, argues that world literature pedagogy continues to be Eurocentric because of its implied audience, adding that anthologies are a good example of this problem because they tend to take as their "central premise that American university students are the primary stakeholders" (76). Indeed, Mufti acknowledges that the reader of world literature criticism is almost always imagined to be Euro-American (xi).

These issues of implied readership and the English language are rooted in our colonial pasts. Mufti asserts that because colonial projects were in part also Westernization projects, "the transformation and rationalization of at least segments of native society along bourgeois-European lines" (23), world literature is "inseparable from the rise of English as a global literary vernacular" (11). He calls it a "formidable structure of cultural domination" (24, emphasis his), placing the English language as the central problematic in world literature. Today, in our globalized, capitalist world, English continues to enjoy foremost status as both the lingua franca of cross-cultural communication and the language of opportunity. No longer a direct colonial imposition but a financial necessity, English is essential "to compete for jobs, and move upwards in labor markets" (Pratt "Languagescapes" 277). Indeed, it is a "universal language"3

not determined by the number of its speakers of that language but by the number who depend on it for their survival. Outside of the Anglo-European sphere, a linguistic and cultural hierarchy has emerged in which English, with its access to the latest knowledge and technology, stands at the top while national and other local languages stand below.

SHIRANE 361, emphasis added

This "linguistic gatekeeping," as Mary Louise Pratt puts it ("Languagescapes" 277), has made it so that students strive to learn or improve their English at American-style universities (i.e. with credit hours following a liberal arts model) outside North America, at universities that exist as satellite institutions or independent local ones, to open up opportunities for themselves, and this is as true in the Middle East, where I teach, as it is in China (Shirane 362 ) and Mexico (Pratt "Languagescape" 277). Its status is further strengthened by the fact that oftentimes students themselves want to learn about America because of the American products they consume and the "cool" American music they

3 Shirane here is discussing contemporary Japanese novelist Minae Mizumura's use of "universal language" in her academic book, The Fall of Language in the Age of English. 
listen to (Chilton 79-81). ${ }^{4}$ As Paul Jay puts it, it has become "nearly impossible to figure out where economic globalization stops and cultural globalization begins ... as systems of commodity exchange are also systems of cultural exchange" $(80 ; 84)$.

Given these problems and the status of English as the language of opportunity, the questions that arise in the world literature classroom should be different from those that arise in U.S.-centered debates in the field. These questions must address what world literature looks like in our globalized, Englishspeaking world. What forms does it take when world literature courses are as much an effort to make a young, educated generation more informed about distant cultures as it is about honing their command of English? If "during the period of colonialism all the colonized countries were learning Western literature as world literature while denigrating their own productions as vernacular, indigenous, and subworldly" (Radhakrishnan 1398), can world literature remedy that by teaching local literature? For me, teaching at a university whose student population comes from over 85 different countries, unable to cross borders as freely as the texts that they read, which "local" literature would that be? What "foreign understanding" would a course in world literature offer? Would a world literature course also be a postcolonial one? Would it be a version of folklore studies, or a component of area studies? What would an "inclusive" world literature course look like if one was never imagined as the primary reader (and speaker) of English?

This complexity weighs on me whenever I teach world literature precisely because of the historical and geographical complexity of our increasingly globalized world. Ever since I heard the term world literature, it came with the loose definition of studying texts from different parts of the world to gain a better understanding of different (linguistic) cultures. While a laudable premise, which continues to have central importance in any world literature classroom, I found this approach peculiar. Spending my childhood in at least four different countries with different national languages, I did not formally study Arabic, which is supposed to be my "mother tongue," until I was at university, and even then, it was the Arabic-for-foreigners course. When I attended graduate school in the U.S., I always failed native informant tests. As such, this approach of learning about different cultures did not make sense to me

4 There is no denying how pervasive American culture has become, especially because of the Internet and its heightened use as a result of the coronavirus pandemic. This culture travels through social media, Netflix and other streaming devices, Amazon.com bestseller recommendations, music, fashion, and even movements such Black Lives Matter, which witnessed worldwide demonstrations of solidarity in the summer of 2020 . 
because what does it mean to read texts from specific parts of the world if many of these peoples are already multilingual, multicultural, practice multiple religions, and have trouble pinpointing a "home" culture, place, or even language as their own? The very idea of singular cultures seemed absurd. Was there a space for this complexity in a world literature course? Furthermore, colonization took different shapes and forms in different parts of the world, with different lingering effects in different parts of the world, complicating the matter further.

When I was first assigned to teach world literature, I tried to grapple with this complexity in my classroom mainly because many of the students have similar experiences to mine. Most are not Emirati, and even if they are, some speak English much better than they do Arabic. If I am teaching an Arabic text in translation, I always give students the option of reading it in the original if they want to. While, of course, some do, the majority tell me reading in Arabic is slow and difficult, and that they prefer to read it in the English translation.

This complexity, I find, is essential to the field of world literature, and it should prompt reflection on the logic of world literature as it is practiced and debated in English in academic centers. What I do here is explore what world literature could mean given such a context. I use my own experience teaching world literature in the United Arab Emirates, where the student body is mostly Muslim and comprised of over 85 nationalities from the Arab region, Southeast Asia, and northern Africa. The goal of this exploration is to wager a new purpose for world literature with a global reading public in mind, one that is seldom the implied addressee of not only literature in English but of scholarship about world literature pedagogy. I hope to do this in an analysis of Mohja Kahf's The Girl in the Tangerine Scarf (hereafter Tangerine Scarf), using it to make a global claim on world literature.

Why Tangerine Scarf? English, Globalization, and the Migrant Writer

Tangerine Scarf is a semi-autobiographical, coming-of-age novel about a young girl whose strict Muslim family immigrates to rural Indiana from Syria in the early 1970s. Khadra, the novel's narrator and protagonist, grows up in a strict, religious household as her father works as an officer at the Dawah community center. Though she experiences Islamophobic violence as she grows up, by the time she narrates her story as an adult, she has come to terms with her place as a Muslim in America. Her background and the transnational scope of her story resonates well with my students, enabling it to speak to multiple readers, 
those in the position of the "implied" hegemonic, Euro-American gaze, but also to those who are not.

It has been argued that "the pertinent world literature discourses take on the phenomenon of the migrant writer, most of whom, funnily enough, write in English" (Chilton 94). I would like to suggest that this is not necessarily a shortcoming; rather, it is precisely what makes Anglophone literature in a world literature classroom so powerful. Mary Louise Pratt maintains that literature is "worlded" when it allows for a transnational reading public, arguing that this iteration of "world literature" comes at the heels of decolonization and is led by immigrants whose "worlded storytelling" "not only navigates globalization, but seeks to engage it" ("Languagescape" 285). Following Pratt, who argues that "migration, decolonization, and travel together produced the 'worlding' of literature" (285), by studying such texts, the central questions in a world literature classroom are no longer how to make world literature more "inclusive," but rather become how to make the lingua franca, English, more worldly. In other words, how can the language of power and opportunity, the global literary vernacular, articulate the most important and most banal experiences of those who speak it beyond Euro-American centers, oftentimes as their own "mother" tongue?

I recognize that the ubiquity of English is especially controversial because of the disheartening fact that the number of languages in the world has decreased as a result of both colonialism and globalization (Mufti 12; Pratt "Languagescapes" 278). Of course, I am in no way advocating a move towards monolingualism and continue to be frustrated by the fact that I, along with many of my students, know Arabic and its literary tradition less proficiently than I'd like to. Nevertheless, refusing to recognize the ubiquity of English can refuse its readers and speakers the opportunity to see themselves as subjects of what qualifies as "literature." Indeed, since "the many worlds opened up by globalization are increasingly likely to be known through that [English] single language alone" (Shirane 357), it is important that these worlds are also explored in English. As Adichie shows in her talk "The Danger of a Single Story," because she grew up reading stories about people talking about the weather and blue-eyed children eating apples - things rather foreign to her Nigerian childhood - when she herself began to write stories as a child, her characters were also blue-eyed, appleeating children who played in the snow. Reading such stories as a child implied that this is what literary characters are supposed to look like and do. She thus argues that "single stories" such as these are dangerous because they make one believe their own stories do not belong in the "global literary vernacular."

In this way, I find that migrant literature such as Tangerine Scarf enables us to explore how the global literary vernacular accommodates those experiences, 
cultures, and religions in a post-colonial, transnational, globalized world. This is an incredibly important role for world literature. It can be subversive as it exposes the fact that no one people can actually "own" a language like English (Pratt 279), and, in that vein, that no one people are its sole implied readers. With this in mind, I argue that migrant literature such as Tangerine Scarf allows non-American and non-European worldviews a voice in hegemonic discourses and languages precisely because it is written in English. As such, literature in English is no longer necessarily an extension of the imperialist project, directed at one kind of western implied reader, or a flattening of differences; rather, it becomes an articulation of them.

\section{$2 \quad$ Tangerine Scarf and Its Transnational Reading Public}

Tangerine Scarf was written and published on the heels of $9 / 11$, the Afghanistan and Iraq wars, and intensifying Islamophobia in the US and Western Europe. Given this socio-political context, and alongside Kahf's other writings, critical and imaginative, the novel has always been read as a way to "build bridges" between Christianity and Islam. Furthermore, readings have assumed an American or Arab American implied reader. ${ }^{5}$ Of course, Americans (Arab-, Muslim-, or otherwise ${ }^{6}$ ) are not the only ones who read the novel, and so, like with world literature and world literature scholarship, freeing ourselves of that assumption opens up a myriad of possibilities for the novel, especially as world literature.

One of the major metaphors used to describe world literature is windows on the world, referring to its function as offering a snapshot of the foreign, whether foreign time periods, cultures, or places, and it lines up with the "building bridges" approach to reading. In this vein, Tangerine Scarf has been said to "demystif[y] Muslim lives and practices in the United States," and of

5 See for instance Salaita, Naous, Muttawwa, Aghasi.

6 I struggle with these identitarian categories because they are problematically discrete in their connotations. American tends to imply white Christians, but African-Americans, ChineseAmericans, Latin-Americans, other euro-Americans, and indeed any American can just as easily fit into this category. Similarly, Arabic tends to imply Muslim, even though many nonMuslim peoples including Christians of a myriad of denominations as well as Armenians and Jews use Arabic as a "first" language. In fact, many Muslims do not speak Arabic beyond their religious lives, for instance Indonesians, Iranians, and Pakistanis, complicating the overly simplified significations of these terms. Indeed, this is part of the importance "worlded" world literature and part of the importance of this novel as it refuses the discrete separateness of these identities. 
"altering misconceptions about Muslim women" (Mattawa 87). As Damrosch argues, though, windows on the world are also self-critical windows onto one's own world ("What is World Literature?" 14), exercises in self-critical reflection. As a novel written by an immigrant, Tangerine Scarf engages with and problematizes the metaphor because it complicates what is considered foreign and one's "own," especially in a post-colonial age of migration and globalization.

As literature in English, Tangerine Scarf is American, Arab, and Muslim all at the same time. It resists being nationalized or made to represent a single identity, whether this identity is religious (Muslim), cultural (Arab or "western"), or national (American or Syrian), and its trans-communal character stems from the fact that it is written in English. Khadra, Tangerine Scarf's protagonist, feels both at home and foreign in the US, at home in her religion but foreign to many of its community's beliefs, and at home in Syria but alienated from its governing regime. As such, it is able to address multiple readers, who can at once be Muslim, Christian, Jewish, and so on; Arab, American, or immigrant; men, women, or non-binary. It speaks not only to a complex "transnational reading public" (Pratt "Languagescapes" 285), but to a trans-religious, trans-cultural, and translingual one, thereby revealing the power dynamics of our world and offering a "radical critique" of asymmetrical globalization in which English plays a central role (Mufti 12).

Khadra's sense of feeling alienated in one's home is a key experience for migrants, and the novel reproduces this sense of alienated at-home-ness for its "trans-" reading public. As the reader encounters the familiar, the novel also defamiliarizes it, subversively resisting identarian readings as well as the assumed homogeneity of imagined communities. A clear example of this is its motif of the titular scarf. The scarf, veil, or hijab has been excessively politicized, whether in the US because of 9/11, in Europe with the French ban on public displays of religion, or in certain Muslim countries where wearing it is mandatory for women. Rather than stand as a metaphor for the silenced woman, her forbidden mystery, and the supposedly intrinsic oppression of Islam (Kahf, Western Representations), the novel depoliticizes the veil and in contrast depicts it as a source of power. Khadra strikingly describes her Muslim mother in hijab as wearing "a white wimple on her head, and a long blue robe" (6); "Her [mother's] sky-blue jilbab swept the ground, and her white crepe wimple outlined her head against the sky" (100). The image of the sacred Madonna and the choice of using the key word wimple, worn not by Muslim terrorists or oppressed women, but by nuns and women saints, disarms the connotations of hijab and familiarizes it to its non-Muslim audiences. It transforms the alienating image of the veil into a familiar and even sacred symbol of salvation. At 
the same time, this description of the veil addresses Muslim readers, reminding them that Islam has no exclusive claim on modesty and head coverings, indeed, that they are as much part of an Islamic tradition as they are of Christian and Jewish ones (worn historically by women of the upper classes as a sign of dignity and modesty [Naous 95]). Renaming the garment thus unravels its Islam(ophob)ic politicization, provides it with "bridge-building" power, and reveals its sacredness in various religions and cultures.

\section{Heterolingual Expressive Practices, Worlded English, and Global Readerships}

Such alienated at-home-ness happens in and because of language. Pratt argues that immigrant literature tends to engage in "heterolingual expressive practices," which are "performances where speakers place more than one linguistic system into play at the same time." For her, these expressive practices "introduce a foreignness into the host language and literary system, a strangeness that carries both danger and possibility, threat and promise, fear and desire" (Pratt "Languagescapes" 288).

The novel is full of such heterolingual expressive practices. As someone who immigrated to the US as a child, Khadra is fully "at home" in English, more comfortable reading translations of Arabic into English (194), and much more expressive in it when she is angry (178). At the same time, this same English language lacks cultural and religious expressions for experiences intrinsic to her everyday existence. The novel remedies this by forcing English to articulate the foreign, most obviously in transliterations of mainly religious expressions such as prayer, verses from the Qur'an, and hadith. Heterolingual expressive practices also appear as Arabic expressions verbalized in English. Like the use of the word wimple, their transfer into English happens in codes of the normal, just as Khadra experiences them in her everyday life. Thus, what might initially be foreign and perhaps even a source of fear is nestled in the familiar, disarming any defensiveness and refusing potential othering. For Muslim and Arab English speakers like my students, these heterolingual expressive practices - from religious practices to large gatherings full of aunts and uncles imbued with codes of hospitality and subsequent over-eating - are energizing. Eager in their recognition of these practices, they speak up about their similar experiences in class. In these moments, they find expression for their quotidian cultural experiences in the hegemonic global literary vernacular, allowing them ownership of English.

An example of this occurs early in the novel when a four-year old Khadra plays on a swing as her father teaches her the fatiha, the first sura of the Qur'an: 
"Bismillah arrahmani 'rahim!" Khadra sang as her father pushed her up. $\cdots$

"Alhamdu lilahi rabil alamin," Eyad yelled on the next swing. ...

"Arrahmani 'rahim!" Khadra called as she climbed into the blue atmosphere like an astronaut.

9

The bismillahs and alhamdulillahs are not so threatening when they are sung by a child to the rhythm of her swing. Indeed, the sheer normalcy of the scene, a little girl on a swing with her father in middle America, along with the reference to an astronaut at the height of the Cold War - the context of this scenemakes this moment as American as it is Muslim. In another instance, Khadra's melodious description of prayer reads almost as a how-to guide for how Muslims pray, as Naous puts it, as an "Islam 101 course" (83). It is focalized through a young Khadra, herself learning how to pray, once again familiarizing the process through an innocent child's eyes:

First position, qiyam. Standing, feet planted hip-distance apart for balance, focus before you raise your arms in allahu. "Straighten your lines, close those gaps - stand shoulder to shoulder and foot to foot," the imam at Salam Mosque said before he called the first allahu. "Shaytan gets between you if you leave a gap." Like one of the pushy boys in the lunch line at school, Khadra imagined. She squinched close up against Tayiba and tugged Hanifa's arm to pull her into line. "No pushy Shaytan gonna get between us, hunh."

... You went into ruku. The bow, with your knees locked and back straight as a table - someone should be able to put a full glass on your back without spilling. You whispered your subhana-rabial-atheems, looking down at your toes in their own little lines. Here comes the signal to rise ...

Now you dropped into sajda, prostration. No flopping elbows on the floor, because that's a dog posture and Muslims don't do dog. Humility yes, dog no. Seven surfaces only touch the mat during sajda: Palm, palm, knee, knee, foot, foot, forehead. There, after three subhanas, you whispered your private prayers, nose brushing the bumpity carpet. You left room for a baby. If Khadra's brother Jihad was lying there, say, she should be able to make the sajda over him. (And maybe give him a little belly tickle along the way).

$3^{2}-33$ 
Though Arabic is the language of the Qur'an, which is forbidden from being translated, the novel provides conceptual equivalents for Islamic practices in English (qiyam, standing; ruku, the bow; sajda, prostration). Describing and explaining prayer by both transliterating and translating the Arabic carves out a space for Islam in hegemonic English, and this allows students such as mine to, as Adichie shows, see their own daily, religious practices in the global literary vernacular. As Tangerine Scarf places them in the "host" language, these heterolingual expressive practices also legitimate the foreigner's sense of ownership of this universal language.

Interestingly, I once asked my students who they think the implied audience of the novel is. Contrary to my expectations, many answered a Muslim one because, as they put it, another audience would not understand these religious postures or references. Their reaction revealed the power relations inherent in English and the asymmetry of globalization: the expectation that Muslim references will not be understood by non-Muslims; indeed, that this non-Muslim audience is not even expected to understand them. At the same time, these same students find it natural to make an effort to understand American (or British or even "Christian") cultural references - on television, in film, social media, and literature. Invoking Damrosch, I suggested to them that the novel can be read as a "window on the world," as an effort to show an Islam not related to stereotypes of terrorism or fundamentalism. At first, the thought surprises them, as though they never considered the possibility, but they, of course, welcome the thought of these practices being read outside paradigms of terrorism and Islamophobia.

Heterolingual expressive practices in the novel are not necessarily religious but cultural too, for instance, the recurring te'ebrini that Khadra's teta uses to address her. Te'ebrini is a term of endearment which literally translates as "may you bury me," and it implies her wish that Khadra outlives her great aunt because she, in short, cannot live without her. Teta too is an expressive cultural practice. It is a Levantine abbreviation of sitt, a term of respect for an older woman used mainly for grandmothers. At the end of the novel, when Sabriya, a member of Khadra's community, has a baby daughter, one of the aunts tells Khadra, "May you be next, marriage and a baby" (418). This is a direct translation of 'ala qbālek, literally, in your future, a small prayer usually repeated at engagements, weddings, and when a baby is born, a phrase implying that both are in Khadra's near future. It is unclear whether this phrase is spoken in English or not in the novel, but such moments in the novel delight my students, even if they do not speak Arabic. Arabic, Urdu, or Hindi speakers swear they've heard their own community members say the "exact" same thing to them. 
The novel makes it clear that despite migration and globalization, and maybe even because of them, the drive to define the parameters of home, although difficult, have become all the more compelling. Alienated at-home-ness puts into relief the incongruity of singular, discrete identity in a globalized world of migration and movement, but also the desire for it. As the novel defamiliarizes the familiar, it foregrounds the violence that results when this incongruity confronts the desire for discrete, homogenous identity - Muslim, American, and Arab alike. As "worlded literature," the novel does this when it offers windows onto one's "own" world, provoking self-critical reflection on one's assumptions about that world.

As mentioned earlier, because windows on the world include both the good and the bad, and because of global power imbalances and the tendency for Islamophobia of the hegemonic gaze, this "airing dirty laundry," so to speak (Salaita 41), can create anxiety. For instance, Khadra is put on a project, to her dismay, for the magazine she works for, Alternative Americas, to do a feature on minority religious communities in Middle America. Forced to critically peer into the world she grew up in - the Dawah community of Indianapolis through her literal-cum-metaphorical camera lens, she observes the bad and the good, and decides to put both in the feature. Afraid of how others might react to what they read, her brother tries to stop her, but she insists:

"You don't have to tell me how harsh the scrutiny is that the Muslim community is under. I know all that. We still need to face our darkness too. Negatives and positives. No, for our own sake, not to pander to them. For the sake of 'studying what our own souls put forth,' you know?" 436

While her brother is anxious about how others will judge his community, Khadra is more concerned about not judging oneself. She further takes the risk because she has faith in her fellow Americans to "see the beauty in it too ... in spite of the Islamophobes and the ignorance out there. I'm counting on the intelligence of the readers" (435-436). This metafictional reference to the novel's real readers has been read as courage that displays "Arab and Muslim Americans in their totality, including the negative, which ultimately makes them more human and thus more likeable" (Salaita 41). Of course, Arabs and Muslims read the novel too, and thus share her brother's anxiety.

Khadra's brother's reaction is not surprising given the hate and violence their community experiences in Indiana. The novel, spanning the 1970s to the 1990s, 
"demonstrate[s] that anti-Muslim attitudes and violence are not merely reactions to the terrorist attacks of 9/11" (Naous 82). Its first word is "Liar," which Khadra says in response to the sign at the state border, "The People of Indiana Welcome You" (1). She knows she is not welcome in Indiana because, in her youth, her community was repeatedly attacked and told things like, "FUCK YOU, RAGHEADS. DIE" (82), and its members are told "BACK [TO] WHERE YOU PEOPLE CAME FROM" (7). This hostility makes the Muslim community insular, constantly afraid, and ignorant of the mysterious Americans amongst whom they live, creating xenophobia in the other direction and reinforcing an easy dichotomy between "us" Muslims and "them" Americans. Indeed, we see that the Muslims feel morally and religiously superior to the "Americans" around them, Americans who are imperialists (69), who smoke, drink, take drugs, get into fights, cuss, and fornicate, and who allow their daughters to roam the streets and let their midriffs show (67-68). This is the America of which the Shamy family asserts it is not a part. In one episode, Ebtehaj, Khadra's mother, scolds her children for staying out late:

She looked like she was about to cry, but what she did was scream. "Do you think we are Americans? Do you think we have no limits? Do you think we leave our children wandering in the streets? Is that what you think we are? Is it?" Then she burst into sobs. She marched Khadra up the stairs and pushed her into the bathtub ("Don't go anywhere!" she yelled at Eyad, "You're next!"). With the water running hot and hard even though their father always said "The Prophet teaches us not to waste, even if we are taking water from a river," she scrubbed and scrubbed her daughter with an enormous loofah from Syria. "We are not Americans!"

$66-67$

In a fit of anxiety, Ebtehaj tries to scrub the "American" off her children, creating in Khadra and her brother an image of the other, and people in her surroundings as well as bullies at school also assert this.

Thus alienated, Khadra imagines herself part of a pure, untainted community of Muslims, with Saudi Arabia at its heart. And so, when Khadra travels there for hajj, the pilgrimage to Mecca, she expects the trip to be a return to her real home, her abode and place of belonging (157). Once there, though, she faces a rude awakening. Expecting Saudi to be untainted by what she perceives are the Evils of America, she is welcomed by Panasonic, Seiko, and Sony billboards upon arrival (161), signaling that globalization and capitalism have penetrated even this sacred place. Furthermore, she is scandalized to encounter youths like herself, boys and girls together, taking drugs and engaging in illicit 
sexual behavior. What fully shatters her sense of being "at home" in Saudi Arabia is that she is repeatedly referred to as the American cousin. What is more, as the American cousin, she is expected to engage in "American" behaviors fornicating, drug-taking - and asked, “don't tell me you never do stuff like this in America - " (177). Shocked, she thinks to herself, "And even though she was in a Muslim country at this moment, and not just any Muslim country but the Muslim country, where Islam started, she had never felt so far from home" (177, emphasis in the original).

The novel uses romance tropes ironically to highlight Khadra's naiveté about her sense of belonging to this imagined community of Muslims. Still in Saudi Arabia, when she is awoken by the fajr call to prayer one dawn, she throws herself out the window to listen to the adhan, "She had run to the window, flinging it open, and leaned her head out in the early morning darkness, as if to bring her whole self closer to the call. It was the long-awaited invitation. She was going to the ball" (166). Responding to the "call of love" (166), she takes herself to the mosque to pray only to be caught by the morality police for being out of the house without her mahram, the male relative in charge of escorting her movement. ${ }^{7}$ Escorted back to her parents, she feels humiliated and asks why women are not allowed to pray in mosques, in Saudi Arabia of all places:

"Women here do not go to the mosque. They don't in most Muslim countries."

Khadra had never heard such a preposterous thing. It couldn't be right. Being a Muslim meant going to the mosque ... "Women have always gone to the mosque. It's part of Islam ... What about Aisha? What about how Omar wished his wife would not go to the mosque for fajr but he couldn't stop her because he knew it was her right? What about the Prophet saying 'You must never prevent the female servants of God from attending the houses of God?"

168 , italics in the original

In spite of her understanding of what a Muslim is "meant" to do, gendered cultural conventions break her heart.

This scene with the morality police upsets many of my students. Like Khadra's brother, some are offended by this "window" on the Muslim world, passionately protesting that women are allowed to pray in mosques in Saudi Arabia - in the women's section, just like in every other mosque in Muslim

7 Literally, the mahram is someone a woman is forbidden from marrying, male blood relatives, milk-siblings, and so on. A woman does not have to wear a veil around these men. 
countries. Wary of the hegemonic gaze and fearing that this gendered injustice is all non-Arabs or non-Muslims will take away from the text, they defensively assert that this is not what Islam "really" is about.

By guiding these discussions of what Islam is really about into discussions of how culture informs religious identity, students are prompted to reflect on diversity in Islam, another central theme in the novel. Indeed, Khadra's experience as a young, immigrant woman problematizes notions of what Islam "really" is and foregrounds the implications of culture on religious practice. For instance, the adult narrator describes how the women of her community wear the veil based on their own cultural backgrounds: "a young woman who is perhaps Bosnian or Eastern European, wear[s] a floral écharpe ... women in hijab, their khimars and saris and jilbabs and thobes and depattas fluttering and sweeping the floor reaching out to everything" (55). Similar diversity also emerges in the various foods eaten at community gatherings, from the carrot cake of Aunt Trish, who is a white American, the samosas made by Aunt Dilshad, who is from Hyderabad (26), the Saudi's kabsa, to the Malaysians' fried squid (52).

Such introspective challenges of difference overlap with another critical argument the novel makes: the diversity of American identity. By the end of the novel, Khadra comes to terms with the fact that she too is an American, just a Muslim one: "She looks around at the white people, too - the Americans no wait, she's American now - the other Americans" (438). Such moments in the novel point to how religion in turn informs cultural identity. Americans have been said to gain their sense of identity from multiple sources including religion, "Part of being an American was having faith in God and belonging to one of the three established religious communities," namely Protestantism, Catholicism, or Judaism (Wuthnow 5). Nevertheless, there is no space for Muslim in American identity in this configuration, and though it is sometimes seen as an other, unwelcome component of American identity, Judaism maintains visibility that the third of the three monotheistic traditions does not. It is not counted as one of the three "established" religious communities in America, though Muslims are woven into its fabric. Other than the Arab Muslims who emigrated to the US from the Ottoman levant in the late 19th and early 2oth centuries, $1^{-20}$ percent of the slave population was in fact Muslim (cited in Naous 102). This creates a dichotomy between Muslim and American, one that is acutely raced and that positions Muslims as the other and hostile to America, indeed, as a source of terror, opposition, and aggression towards American ways of being.

The novel challenges these dichotomies on multiple levels. First, it asserts that African American Muslims are "native" to northern Indiana (Kahf 44). 
It also stresses the settler colonial past and history of slavery that are central to American identity, as can be seen, for example, in the names of one of the aunties in the Dawah community: "Aunt Khadija's name used to be Kacey. Kacey Thompson, then she changed it to Kacey X, then Khadija X, then Khadija Kareem when she became a Bilalian, then Khadija Al-Deen when she married Uncle Jamal" (23). This nominal history exposes the violence of the past and places Islam at the center of what it means to be American. As Aunt Khadija helps Khadra don her veil for prayer, she tells her:

"Imagine being made to stand naked in front of a whole bunch of people," Aunt Khadija murmured.

Khadra drew back with a look of horror.

"Mmm hmm. That's how it was," Aunt Khadija said, her face framed in a plum-colored scarf. "That's how it was in slavery times. Up on the auction block. Covering up is a strong thing."

25

Aunt Khadija here asserts the power of veiling by giving it an acutely American significance in the context of America's history of slavery, asserting this Muslim practice is homegrown because of America's past. "Covering up" does not represent the other or oppressed exotic foreign women; rather, it is an empowering practice needed in America to protect against subjugation and objectification, one that exposes power relations and historical injustices obscured by racist assumptions about identity. Indeed, throughout the novel, Khadra speaks of her veil in those terms, referring to it as her armor $(310,425)$ and her crown $(112,309,313)$, a deliberate metaphor not uncommon in the description of natural hair amongst African Americans (see Banks 10-12, 13, 18, 23, 77).

As mentioned earlier, members of the Dawah community imagine Americans to be a singular kind of people of a single race, ethnicity, and religion; they also see themselves as a singular "us," the victims of white American racism. Such perceptions make it easy to obscure internal prejudices, gender oppression, and outright racism in the name of the "whine [of] minority victimization" (Zine "Interview with Kahf" 251). The Dawah community is, of course, not immune from such racist othering. Members of the community, in spite of its diversity, conflate Arab and Muslim, its Arab members looking down on converts, those who do not speak Arabic, and Shi'a Muslims. They also do not count the Nation of Islam or Bilalism as "real" Islam. Mimicking what she hears from the adults around her, Khadra asks Aunt Khadija: "... were you still that Elijah thing? The fake Muslims where it's only for black people?” (23). 
Khadra, raised on a myriad of rules about what is righteous, shariah, and what is sinful, haram, memorizes all the correct dictates of Islam that the Dawah center teaches, including "the Dawah Center line: No Racism in Islam" (137). Her African American peer Hakim, though, challenges the imagined "us" and "them" of the community by asserting a different "us": "You all is, immigrant brothers and sisters. 'We' is black people." When Khadra angrily tries to correct him, saying that "we" belong to the community of Muslims, Hakim responds,

Oh yeah? How many Dawah officers are black? How many immigrants do you know who've married African American? Be for real! Immigrant white-pleasers'll marry white Americans, Muslim or not, but they won't marry black people

137

As much as she hates hearing this, Khadra deep down knows he is right. She relates the incident where her brother falls in love with Maha, the Sudanese doctor's daughter who "had impeccable character, was active in the mosque, ... wore flawless hijab ... [a]nd, definitely, she was a native speaker of Arabic" (138). When he asks his parents about proposing to her, his father blurts, "But for heaven's sake, she's as black as coal!" (139).

While these instances in the novel seem to address an American reader, they also speak directly to my students. Not unlike Khadra's mother and other members of the Dawah community, they admit to perceiving Americans as a singular type, usually with looser morals than their own. The Maha incident is an important moment of self-reflection. Though they are mostly Muslim, they look very different, and in spite of the shared religion, may have been on one or the other end of a similar experience. Such moments are important teaching moments linked to windows on one's own world.

The racialized ethnocentrism that seems to delimit what it means to be American and what Muslim is also intersected with gender, and the novel highlights how problematic it is when women's bodies become the metaphorized depositories of the struggle for identity. This is especially the case when boundaries of identity are threatened, and xenophobic violence erupts. In the novel, both white Americans and members of the Dawah community participate in this violence. Zuhura, with "darkest ebony skin" (74), is an outspoken, Muslim woman of Kenyan descent who heads the African Students Organization at Indiana University. On her way to a student meeting one evening, she is gang raped and murdered by white supremacists. In spite of this horrendous murder, after she goes missing, the Muslim community begins to speculate 
about her honor, sure that "[e]ven if she is found alive now, she is ruined" (92). Though she is raped and murdered, it is she who is made to bear the responsibility:

"She should not have been traipsing about the highways at midnight night alone," [Khadra's parents] Wajdy and Ebtehaj agreed in late-night kitchen-table voices. And the whispers and undertones around the water cooler at the Dawah Center agreed: She had been asking for trouble. Sad as it made them to say it. And her family should've given her more guidance. You protected your daughters.

$95^{-96}$

Although white supremacists raped and murdered Zuhura, the novel foregrounds how this patriarchal world-view that makes women responsible for violations committed against them is just as violent. This pivotal incident traumatizes the narrator throughout the novel, shaping who she becomes as an adult. Its centrality asserts the violence of exclusive identity and shows that no one group is innocent. It thus foregrounds the dirty laundry of multiple reading publics, turning the world literature classroom into what Pratt has famously called the "contact zone." In such zones,

all students ... had the experience, for example, of hearing their culture discussed and objectified in ways that horrified them; all the students saw their roots traced back to legacies of both glory and shame; all the students experienced face-to-face the ignorance and incomprehension, and occasionally the hostility, of others ... Virtually every student was having the experience of seeing the world described with him or her in it. Along with rage, incomprehension, and pain, there were exhilarating moments of wonder and revelation, mutual understanding, and new wisdom - the joys of the contact zone ... No one was excluded, and no one was safe.

"Contact Zone" 39, emphasis added

Such contact zones are important for any literature course, but in a world literature course they enable what Rajagopalan Radhakrishnan argues is an important component of world literature: "ethicopolitical courage" (Radhakrishnan 1401-1402). This involves opening ourselves up and allowing ourselves to be vulnerable in the world; it goes against "not judging for fear of being judged," and instead becomes an "intimate active dialogue with its corollary of judging for fear of not being judged" (Radhakrishnan 1403). In the context of world literature in which students' cultures are rarely a subject of literature in English 
in spite of the fact that English may be their "first language," such judging for fear of not being judged is critical as it prevents what Kahf has pointed out as the whine of minority victimization. It also engenders the self-critical reflection required to learn about one's own culture, but in the context of contact with others; in other words, in the context of the world, in the context of world literature.

Teaching world literature is a difficult task not least because it is a "field that ideally covers not only the whole geographical world, but also the entirety of literary history" (Smith 585). This is especially true when teaching it in English beyond global academic centers because of the implied hegemonic gaze. Rather than speak to one audience on one side of the power balance, though, Tangerine Scarf, as a novel in English by a migrant writer, is able to speak to multiple audiences, offering up windows on multiple worlds. In this way, it is able to make English, the global literary vernacular, worldly, home to peoples, experiences, cultures, and religions usually perceived as foreign to it. By showing how identities overlap and intersect and by rejecting assumptions about the homogeneity - and therefore superiority - of imagined communities, it transforms world literature from what "other" cultures are like into conversations about vulnerabilities. In this way, world literature in English can move beyond an imperialist paradigm and become an articulation of internal diversity and religious, cultural, and national heterogeneity, equally addressing all readers and not only Euro-American ones.

\section{Acknowledgement}

The work in this paper was supported, in part, by the Open Access Program from the American University of Sharjah.

\section{Works Cited}

Adichi, Chimamanda Ngozi. "The Danger of a Single Story." TED:Ideas Worth Spreading 7 Oct. 20o9. Web.

Aghasi, Maya. "Arts: Fiction and Fiction Writers: United States," Encyclopedia of Women \& Islamic Cultures. Ed. Suad Joseph. Leiden: Brill, 2016. Web.

Banks, Ingrid. Hair Matters: Beauty, Power, and Black Women's Consciousness. New York: New York UP, 200o.

Chilton, Myles. English Studies Beyond The 'Center': Teaching Literature and the Future of Global English. London: Taylor \& Francis, 2015. 
Damrosch, David. "Global Comparatism and the Question of Language." PMLA 128:3 (2013), 622-628.

Damrosch, David. "How American is World Literature?” The Comparatist 33 (May 2009), 13-19.

Damrosch, David. "What is World Literature?" World Literature Today 77:1 (Apr-Jun 2003), 9-14.

D'haen, Theo. "Major Histories, Minor Literatures, and World Authors." CLCWeb:Comparative Literature and Culture 15:5 (2013).

Hodapp, James. "The Problematic and Pragmatic Pedagogy of World Literature," Ariel: A Review of International English Literature 46:1-2 (2015), 69-88.

Jay, Paul. "Globalization and the Postcolonial Condition." In Globalization and the Humanities. Ed. David Leiwei Li. Hong Kong: Hong Kong UP, 2004, 79-100.

Kahf, Mohja. The Girl in the Tangerine Scarf. New York: Carroll \& Graf, 2006.

Kahf, Mohja. Western Representation of the Muslim Woman: From Termagant to Odalisque, Austin: University of Texas Press, 1999.

Mattawa, Khaled. How Long Have You Been With Us?: Essays on Poetry. Ann Arbor: University of Michigan Press, 2016.

Mufti, Aamir. Forget English! Orientalisms and World Literatures. Cambridge: Harvard UP, 2016.

Naous, Mazen. Poetics of Visibility in the Contemporary Arab American Novel. Columbus: Ohio State UP, 2020.

Pratt, Mary Louise. "Arts of the Contact Zone." Profession (1991), 33-40.

Pratt, Mary Louise. "Comparative Literature and the Global Languagescape." In A Companion to Comparative Literature. Eds. Ali Behdad and Dominic Thomas. New Jersey: John Wiley \& Sons, 2011, 273-295.

Radhakrishnan, Rajagopalan. "World Literature, by Any Other Name?" PMLA 131:5 (Oct. 2016), 1396-1396.

Salaita, Steven. Modern Arab American Fiction: A Reader's Guide. Syracuse: Syracuse uP, 2011.

Smith, Karen R. "What Good Is World Literature?: World Literature Pedagogy and the Rhetoric of Moral Crisis." College English 73:6 (2011), 585-6o3.

Suter, Rebecca. “A Two-World Author." In Two-World Literature: Kazuo Ishiguro’s Early Novels. Honolulu: University of Hawai'i Press, 2O2O, 1-22.

Wuthnow, Robert, et al. "Forum: Sources of Personal Identity: Religion, Ethnicity, and the American Cultural Situation." Religion and American Culture: AJournal of Interpretation 2:1 (1992), 1-22.

Zine, Jasmine. "Interview with Mohja Kahf." In Muslim Women, Transnational Feminism and the Ethics of Pedagogy: Contested Imaginaries in Post-9/11 Cultural Practice. Eds. Taylor, Lisa K, and Jasmin Zine. London: Routledge, 2014, 347-251. 